\title{
Oral Infection as a Risk Factor for Preeclampsia
}

\author{
Mona Z Zaghloul \\ Microbiology Unit, Department of Clinical Pathology, Ain Shams University Hospitals, Cairo, Egypt
}

*Corresponding author: Zaghloul MZ, Ain Shams University Hospitals, Cairo, Egypt, Tel: 02-24023494; E-mail: monazaki_810@hotmail.com

Received date: December 21, 2015; Accepted date: January 5, 2016; Published date: January 8, 2016

Copyright: (c) 2016 Zaghloul MZ. This is an open-access article distributed under the terms of the Creative Commons Attribution License, which permits unrestricted use, distribution, and reproduction in any medium, provided the original author and source are credited.

\section{Editorial}

Preeclampsia is a common obstetric syndrome affecting approximately $5-10 \%$ of pregnant women leading to significant maternal mortality and morbidity. Preeclampsia accounts for $25 \%$ of preterm deliveries resulting in adverse neonatal outcome. It is also the third most common direct cause of maternal death in the United Kingdom [1,2]. Preeclampsia is characterized by new onset hypertension exceeding $140 / 90 \mathrm{mmHg}$ and proteinuria exceeding 300 $\mathrm{mg}$ in a 24 hour urine sample, after 20 weeks of gestation in a previously normotensive woman. It is characterized by abnormal vascular response to placentation, reduced organ perfusion, vasospasm, activation of the coagulation system, inflammatory like response, oxidative stress and some perturbation in volume and blood pressure control, affecting the placenta, kidney liver and brain [3-5].

Periodontitis is regarded as a chronic inflammatory oral infection that affects the tooth supporting structures and bone, in which bacteria of dental plaque and calculus and their byproducts are the principal etiologic agents. Teeth, gingival margins and periodontal pockets are places that could harbor bacterial colonization, and that one cubic millimeter of dental plaque contains about (100 million) bacteria [6-8]. Unhygienic oral conditions that results in inflammatory effects as in periodontitis could negatively affect the general health of individuals. A cause and effect relationship between the health condition of the oral cavity and some systemic diseases is attributed to the presence of dental plaque, periodontal and pericoronal infections [9].

There is a positive clinical association between chronic oral infection and various systemic diseases, rheumatoid arthritis, cardiovascular-disease, diabetes mellitus, chronic respiratory diseases and adverse pregnancy outcomes including pre-term low-birth weight and pre-eclampsia [10-13]. Since periodontal pathogens play a role in systemic diseases either through a direct pro inflammatory effect or through indirect host mediated effects triggered by oral infection [14-16]. Both periodontal and pericoronal infections are chronic Gram-negative infections proposed to feature a chronic endotoxins burden that may result in transient translocation of the organisms to the placenta, thereby triggering placental inflammation [11-13]. Host tissues in periodontal infections could mount an immuneinflammatory response to bacteria and their byproducts by activating host-derived cytokines such as interleukins 1 and 6 as well as tumor necrosis factor- alpha (TNF- $\alpha$ ) and prostaglandin E2 (PGE2) resulting in connective tissue destruction and bone loss [7,11]. Herrera et al. [17] mentioned that the early identification of risk factors and the treatment of a symptomatic chronic infections lowered the preceding incidences of preeclampsia, they hypothesized that chronic infections may cause increased maternal cytokine levels sufficient to affect vascular endothelial function, thereby making pregnant women prime individuals for the subsequent development of preeclampsia.
Previous studies in human showed that oral microorganism, including F.nucleatum and Capnocytophaga sputigena were detected in the amniotic fluid of women with intact membranes and in those with preterm labor [18-20]. Moreover, Madianos et al. [21] have assessed the umbilical cord serum for the presence of fetal immunoglobulin M (IgM) to oral pathogen Porphyromonas gingivalis, documenting a fetal humoral response to organisms distant from the intrauterine environment and suggesting that translocation of oral pathogens to the uteroplacental unit may occur. These studies are supporting the possibility that oral bacteria or bacterial products can spread through the blood stream to the placenta.

\section{References}

1. Villar J, Say L, Gulmezoglu AM, Merialdi M, Lindeimer MD, et al. (2003) Eclampsia and pre-eclampsia: A worldwide health problem for 2000 years. In: Critchley H, MacLean A, Poston L, Walker JJ, eds. Preeclampsia-RCOG Study Group Publication, RCOG Press, London.

2. Neilson JP (2004) Pre-eclampsia and Eclampsia. Why Mothers Die 2000-2012. Confidential Enquiry into Maternal and Child Health. RCOG Press, London.

3. Sibai B, Dekker G, Kupferminc M (2005) Pre-eclampsia. Lancet 365: 785-799.

4. Shetty M, Shetty PK, Ramesh A, Thomas B, Prabhu S, et al. (2010) Periodontal disease in pregnancy is a risk factor for preeclampsia. Acta Obstet Gynecol Scand 89: 718-721.

5. Horton AL, Boggess KA, Moss KL, Beck J, Offenbacher S (2010) Periodontal disease, oxidative stress, and risk for preeclampsia. J Periodontol 81: 199-204.

6. Genco RJ (1996) Current view of risk factors for periodontal diseases. J Periodontol 67: 1041-1049.

7. Iacopino AM, cutler CW (2000) Pathophysiological relationships between periodontitis and systemic disease: recent concepts involving serum lipids. J Periodontol 71: 1375-84.

8. Sixou JL, Magaud C, Jolivet-Gougeon A, Cormier M, Bonnaure-Mallet M (2003) Microbiology of mandibular third molar pericoronitis: incidence of beta-lactamase-producing bacteria. Oral Surg Oral Med Oral Pathol Oral Radiol Endod 95: 655-659.

9. Raghavendran K, Mylotte M, Scannapieco F (2000) Nursing homeassociated pneumonia, hospital-acquired pneumonia and ventilatorassociated pneumonia: the contribution of dental biofilms and periodontal inflammation. Periodontal 44: 164.

10. Redman CW, Sacks GP, Sargent IL (1999) Preeclampsia: an excessive maternal inflammatory response to pregnancy. Am J Obstet Gynecol 180: 499-506

11. Boggess KA, Lieff S, Murtha AP, Moss K, Beck J, et al. (2003) Maternal periodontal disease is associated with an increased risk for preeclampsia. Obstet Gynecol 101: 227-231.

12. Brewster JA, Orsi NM, Gopichandran N, Ekbote UV, Cadogan E, et al. (2008) Host inflammatory response profiling in preeclampsia using an invitro whole blood stimulation model. Informa health care USA 27: $1-16$. 
13. Parihar AS, Katoch V , Rajguru SA, Rajpoot N, Singh P, et al. (2015) Periodontal Disease: A Possible Risk-Factor for Adverse Pregnancy Outcome. J Int Oral Health 7: 137-42.

14. Mumghamba EG, Pitiphat W, Matee MI, Simon E, Merchant AT (2004) The usefulness of using Ramfjord teeth in predicting periodontal status of a Tanzanian adult population. J Clin Periodontol 31: 16-18.

15. Pink R, Simek J, Vondrakova J, Faber E, Michl P, et al. (2009) Saliva as a diagnostic medium. Biomed Pap Med Fac Univ Palacky Olomouc Czech Repub 153: 103-110.

16. Scannapieco FA, Genco RJ (1999) Association of periodontal infections with atherosclerotic and pulmonary diseases. J Periodontal Res 34 340-345.
17. Herrera JA, Chaudhuri G, Lopez-Jaramillo P (2001) Is infection a major risk factor for preeclampsia? Med Hypotheses 57: 393-397.

18. McDonald H, Gordon DL (1988) Capnocytophaga species: a cause of amniotic fluid infection and preterm labour. Pathology 20: 74-76.

19. Chaim W, Mazor M (1992) Intraamniotic infection with fusobacteria. Arch Gynecol Obstet 251: 1-7.

20. Bearfield C, Davenport ES, Sivapathasundaram V, Allaker RP (2002) Possible association between amniotic fluid micro-organism infection and microflora in the mouth. BJOG 109: 527-533.

21. Madianos PN, Lieff S, Murtha AP, Boggess KA, Auten RL Jr, et al. (2001) Maternal periodontitis and prematurity. Part II: Maternal infection and fetal exposure. Ann Periodontol 6: 175-182. 